\title{
Multilevel Analysis Association of Soil Transmitted Helminths and Stunting in Children Aged 6-12 Years Old in Pinrang District, South Sulawesi
}

\author{
Putri Andini Muslimah'), Harsono Salimo²), Yulia Lanti Retno Dewi ${ }^{3}$ ) \\ ${ }^{1)}$ Masters Program in Public Health, Universitas Sebelas Maret \\ 2)Department of Pediatrics, Dr. Moewardi Hospital, Surakarta \\ 3)Faculty of Medicine, Universitas Sebelas Maret
}

\section{ABSTRACT}

Background: Stunting in children is often associated with infectious diseases, one of which is Soil Transmitted Helminths (STH). Worms in children affect the intake, digestion, absorption and metabolism of food which has an impact on reducing the supply of nutrients to the body. This study aimed to determine the relationship between STH and the incidence of stunting in children aged 6-12 years in Pinrang, South Sulawesi.

Subjects and Method: This was an analytic observational with cross sectional design. The study was conducted in Pinrang Regency, South Sulawesi, from January to March 2020. A sample of 200 children aged 6-12 years was selected by random sampling. The dependent variable was stunting. The independent variables were worm disease, maternal education, family income, number of family members, maternal body height, low birth weight, length of birth, exclusive breastfeeding, and complementary feeding. The data were collected by questionnaire and analyzed by a multiple multilevel logistic regression run on STATA13.

Results: The risk of stunting increased with worms $(b=2.11 ; 95 \% \quad C I=1.11$ to $3.10 ; p$ $<0.001)$, low maternal education $(b=1.08$; $95 \%$ $\mathrm{CI}=0.13$ to $2.03 ; \mathrm{p}=0.025)$, low income $(\mathrm{b}=$ $1.03 ; 95 \% \mathrm{CI}=0.05$ to $2.02 ; \mathrm{p}=0.039)$, number of family $(b=2.13 ; 95 \% \mathrm{CI}=1.13$ to $3.13 ; \mathrm{p}<$
0.001), short maternal height $(b=1.03 ; 95 \%$ $\mathrm{CI}=0.10$ to $1.96 ; \mathrm{p}=0.030)$, LBW $(\mathrm{b}=1.45$; $95 \% \mathrm{CI}=0.38$ to $2.51 ; \mathrm{p}=0.007$ ), short birth length $(b=1.91 ; 95 \% \mathrm{CI}=0.95$ to $2.87 ; \mathrm{p}<$ o.001), and inappropriate complementary feeding $(b=1.11 ; 95 \% \mathrm{CI}=0.21$ to $2.11 ; \mathrm{p}=0.029)$. The risk of stunting decreased with exclusive breastfeeding $(b=0.96 ; 95 \% \mathrm{CI}=0.23$ to 1.91 ; $\mathrm{p}=0.045$ ). Village had negligible contextual effect on the stunting with $\mathrm{ICC}=8.2 \%$.

Conclusion: The risk of stunting increases with worms, low maternal education, low income, number of family, short maternal height, LBW, short birth length, and inappropriate complementary feeding. The risk of stunting decreases with exclusive breastfeeding. Village has negligible contextual effect on the stunting.

Keywords: stunting, soil transmitted helminths

\section{Correspondence:}

Putri Andini Muslimah. Masters Program in Public Health, Universitas Sebelas Maret, Jl. Ir. Sutami 36A, Surakarta 57126, Central Java. Email: ptriandn15@gmail.com. Mobile: +6285331663133 .

\section{Cite this as:}

Muslimah PA, Salimo H, Dewi YLR (2020). Multilevel Analysis Association of Soil Transmitted Helminths and Stunting in Children Aged 6-12 Years Old in Pinrang District, South Sulawesi. J Epidemiol Public Health. 05(03): 372-383. https://doi.org/10.26911/jepublichealth.2020.05.03.11.

cc) (i) (2) Journal of Epidemiology and Public Healthis licensed under a Creative Commons Attribution-NonCommercial-ShareAlike 4.0 International License.

\section{BACKGROUND}

Stunting is a measure of chronic malnutrition as the most common form of malnutri- tion in children in developing countries (Hagos et al. 2017). The prevalence of stunting according to UNICEF/WHO/- 
World Bank Group (2019) affects around 21.9\% or 149 million toddlers worldwide. There are approximately 9 million children aged 0-59 months old with the condition of continuing stunting until 6-18 years old.

This condition is more clear for Indonesia, which shows a trend (tendency) for non-communicable disease to increase from 2007 to 2013, where it is estimated that 70 million adult people ( $>18$ years old) suffer from non-communicable disease (Ministry of Health of the Republic of Indonesia, 2018). In 2018, there was an increase from the previous year to $30.8 \%$ which made Indonesia got the the fourth rank in the world (Ministry of Health of the Republic of Indonesia, 2018b). The incidence of stunting in South Sulawesi also in the fourth rank in all of Indonesia. The prevalence of stunting in Pinrang Regency was 43.6\% in 2017, this makes Pinrang Regency as the fifth largest stunting rate in South Sulawesi (South Sulawesi Provincial Health Office, 2018).

The incidence of stunting in children is influenced by various factors, one of them is infectious diseases, such as the incidence of worm infections. Worms can make children experience digestive disorders and protein absorption so that children experience growth problems and acute anemia due to malnutrition. Infectious disease has a significant relationship ( $\mathrm{p}<0.05$ ) with the incidence of stunting (Fitria, 2017).

Another factor related to the incidence of stunting is maternal education, the level of mother's education will influence the mother's attitude and mindset in paying attention to food intake so that it will affect the choice of food that will determine the nutritional status of the child (Rozali, 2016) Family income is also related to the incidence of stunting, high family income can be a factor in fulfilling food needs, nutritional needs both in terms of quality and quantity as well as health care for all family members (Andriani M, 2014). Families who have a large number of children or family members, especially those with less economic conditions are the cause of stunting, this is due to the inability to fulfill food needs and the inability to pay attention to all children or family members they have (Candra, 2011). Height is a form of genetic expression and is a factor passed on to children and is associated with the incidence of stunting (Ibrahim et al. 2019).

In addition, babies born with low birth weight (LBW) will experience obstacles in their growth and development (Azriful et al. 2018), birth length (Swathma et al. 2016), history of exclusive breastfeeding (Kusumawardhani, 2017), History provision of complementary foods (Paramashanti et al. 2016) also has a direct relationship with the incidence of stunting which, if not improved, nutritional intake in the early stages of growth will lead to various kinds of diseases that are detrimental to children.

Therefore, researchers are interested in conducting study on "multilevel analysis of the relationship of soil transmitted helminths (sth) and the incidence of stunting in children aged 6-12 years in Pinrang Regency".

\section{SUBJECTS AND METHOD}

\section{Study Design}

This was an analytic observational study with a cross-sectional design. The study was conducted in Pinrang Regency from January to March 2020.

\section{Population and Sample}

The source population in this study were children aged 6-12 years in 25 sub-districts in Pinrang Regency. A sample of 200 children aged 6-12 years was selected by simple random sampling. 


\section{Study Variable}

The dependent variable was stunting. The independent variables were worm disease, maternal education, family income, number of family members, height of the mother, low birth weight, length of birth, exclusive breastfeeding, complementary feeding, and village level.

\section{Definition of Operational Variable}

Worms is the finding of intestinal nematode eggs or larvae in children 6-12 years based on the results of examination of stool samples. Categorical data scale. Code o: no worms, 1: worms.

Maternal education is the last type of formal education completed by mothers. Categorical data scale. Code o: high school education to college, 1 : elementary to junior high school.

Family income is the average income obtained in one family, adjusted to the MW Pinrang Regency (Rp. 2,860,000). Continous data scale, converted to categorical during data analysis. Code $\mathrm{o}$ : $\geq$ Minimum wage, 1 : $<$ Minimum wage.

Number of family is the number many family members in one household. Continous data scale, converted to categorical during data analysis. Code o: number of family members $\geq 4$, 1 : number of family members $>4$.

Maternal height is the mother's current height as measured at the time of data collection. Measured using microtoise. Continous data scale, converted to categorical during data analysis. Code o: Height $\geq 150 \mathrm{~cm}, 1$ : Height $<150 \mathrm{~cm}$.

Low birth weight is the weight of the child at birth $<2,500$ grams (Ministry of Health of the Republic of Indonesia, 2013). Categorical data scale. Code o: No LBW, code 1: LBW

Birth length is the length of the child's body at birth, the standard size of the child's birth length is $48 \mathrm{~cm}$ (Ministry of
Health of the Republic of Indonesia, 2013). Categorical data scale. Code o: Body length at birth $\geq 48 \mathrm{~cm}, 1$ : body length at birth $<48$ $\mathrm{cm}$.

Exclusive breastfeeding is a history of breastfeeding from 0-6 months old without other food or drink. Categorical data scale. Code o: exclusive breastfeeding, 1: nonexclusive breastfeeding.

Complementary feeding is a history of complementary feeding starting from 6 months old. Categorical data scale. Code o: Getting complementary food, 1: Not getting complementary food.

Sub-district is the strata or level of the village with the topography in Pinrang Regency. Categorical data scale. Code 1: Altitude 0-100 masl, 2: altitude 100-400 masl, 3: altitude 400-1,00o masl, 4: altitude> 1,000 masl.

\section{Study Instrument}

The study instrument used for data collection was a questionnaire that had been tested for validity and reliability, medical records (KIA book), laboratory tests. The questionnaire was used to measure maternal education, family income, number of family members, maternal height, exclusive breastfeeding, complementary feeding. Medical records were used to measure LBW, birth length. Laboratory tests were used to measure the incidence of worms.

\section{Data Analysis}

Univariate analysis to find out the frequency distribution and percentage of characteristics of study subjects. Bivariate analysis to determine the relationship between the dependent variable and the independent variable using the chi-square test. Multivariate analysis using logistic regression analysis through a multilevel approach with

Stata13 program to determine the effect of level 2 (sub-district) on child development. 


\section{Study Ethic}

Ethical clearance in this study was obtained from the Health Research Ethics Commission of the Moewardi Hospital, Surakarta City with number 1,284/XII/HREC/2019 which was published on December 3, 2019.

\section{RESULTS}

\section{Sample Characteristics}

The characteristics studied included worm infection status, maternal education, family income, number of family members, maternal height, age, low birth weight, birth length, exclusive breastfeeding, complementary feeding and sub-districts. These characteristics can be shown in Table 1 and Table 2.

\section{Bivariate Analysis}

Bivariate analysis using the chi-square test. Bivariate analysis based on the results of this study can be seen in table 3 .

3. Multilevel Analysis

Table 1. The Characteristics of Study Subjects (Continous Data)

\begin{tabular}{lccccc}
\hline \multicolumn{1}{c}{ Variables } & $\mathbf{N}$ & Mean & SD & Min. & Max. \\
\hline Income (rupiah) & 200 & $3,116,500$ & 4392247 & 0 & 54, OOO,OOO \\
Number of family & 200 & 4.635 & 1.435996 & 3 & 11 \\
Maternal body height (cm) & 200 & 153.24 & 7.061994 & 132 & 169 \\
Age (years old) & 200 & 8.99 & 2.319158 & 6 & 12 \\
LBW (gram) & 200 & 2.777 & .4348754 & 2.1 & 4.3 \\
Birth length (cm) & 200 & 47.72 & 2.319158 & 39 & 53 \\
Z-score (bh/a) & 200 & -1.67245 & 1.2778 & -3.96 & 3.52 \\
\hline
\end{tabular}

\section{The effect of maternal education} on stunting

There was an effect of maternal education on the incidence of stunting in children aged 6-12 years. Children with low-educated mothers had logodd of experiencing stunting by 1.08 units higher than children with highly educated mothers $(b=1.08$; $95 \% \mathrm{CI}=0.13$ to $2.03 ; \mathrm{p}=0.025$ ).

\section{The effect of family income on stunting}

There was an effect of family income on the incidence of stunting in children aged 6-12 years. Children with low income families
Multilevel analysis explained the effect of more than one independent variable (worm disease, gender, maternal education, family income, number of family members, maternal height, LBW, birth length, exclusive breastfeeding and complementary feeding) with the dependent variable (stunting). The results of multivariate analysis of the incidence of stunting using multiple logistic regression with a multilevel approach can be seen in Table 4 .

Table 4 shows that:

\section{The Effect of Worms Infection Status on Stunting}

Based on Table 4, it can be seen that there was an effect of infection status of worms on the incidence of stunting in children aged 6-12 years. Children with worms had a logodd probability of experiencing stunting by 2.11 units greater than children without worms. $(b=2.11$; CI 95\% $=1.11$ to $3.10 ; p=$ $<0.001$

\section{had logodd of experiencing stunting by 1.03} units greater than children with highincome families $(b=1.03 ; 95 \% \mathrm{CI}=0.05$ to 2.02; $\mathrm{p}=0.039$ ).

\section{The effect of number of family on stunting}

There was an effect of the number of family members on the incidence of stunting in children aged 6-12 years. Children who have a number of family members $\geq 5$ were more likely (logodd) to experience stunting by 2.13 units than children who have a number of family members of $<5(b=2.13$; $95 \% \mathrm{CI}=1.13$ to $3.13 ; \mathrm{p}<0.001$ ). 
Muslimah et al./ Soil Transmitted Helminths and Stunting in Children Aged 6-12 Years Old

Table 2. The Characteristics of Study Subjects (Dichotomy Data)

\begin{tabular}{llcc}
\hline \multicolumn{1}{c}{ Variables } & \multicolumn{1}{c}{ Category } & n & \% \\
\hline Stunting & Normal & 107 & 53.3 \\
Worm infection status & Stunting & 93 & 46.5 \\
& No & 118 & 59.0 \\
Gender & Yes & 82 & 41.0 \\
& Male & 99 & 49.5 \\
Maternal education & Female & 101 & 50.5 \\
& <Senior high school & 86 & 43.0 \\
Family income & $\geq$ Senior high school & 114 & 57.0 \\
Number of family member & $<$ Minimum wage & 109 & 54.4 \\
& $\geq$ Minimum wage & 91 & 45.5 \\
Maternal height & $\geq 5$ & 127 & 63.5 \\
& $<150$ cm & 73 & 36.5 \\
Low birth weight & $\geq 150$ cm & 70 & 35.0 \\
& Not LBW & 130 & 65.0 \\
Birth length & LBW & 144 & 72.0 \\
\multirow{2}{*}{ Exclusive breastfeeding } & $<48 \mathrm{~cm}$ & 56 & 28.0 \\
\multirow{2}{*}{ Complementary feeding } & $\geq 48 \mathrm{~cm}$ & 75 & 37.5 \\
& Not exclusive breastfeeding & 125 & 62.5 \\
& Exclusive breastfeeding & 73 & 36.5 \\
& Not in time & 127 & 63.5 \\
& In time & 77 & 38.5 \\
\hline
\end{tabular}

Table 3. Bivariate Analysis

\begin{tabular}{|c|c|c|c|c|c|c|}
\hline \multirow{3}{*}{ Independent Variables } & \multicolumn{4}{|c|}{ Stunting } & \multirow{3}{*}{ OR } & \multirow{3}{*}{$\mathbf{p}$} \\
\hline & \multicolumn{2}{|c|}{ Normal } & \multicolumn{2}{|c|}{ Stunting } & & \\
\hline & $\mathbf{n}$ & $\%$ & $\mathbf{n}$ & $\%$ & & \\
\hline \multicolumn{7}{|l|}{ Worm infection status } \\
\hline No & 79 & 67.0 & 39 & 33.0 & \multirow[t]{2}{*}{7.55} & \multirow[t]{2}{*}{$<0.001$} \\
\hline Yes & 28 & 34.1 & 54 & 65.9 & & \\
\hline \multicolumn{7}{|l|}{ Maternal education } \\
\hline$<\mathrm{HS}$ & 37 & 43.1 & 49 & 56.9 & \multirow[t]{2}{*}{2.73} & \multirow[t]{2}{*}{0.026} \\
\hline$\geq \mathrm{HS}$ & 70 & 61.4 & 44 & 38.6 & & \\
\hline \multicolumn{7}{|l|}{ Family income } \\
\hline$<\mathrm{MW}$ & 40 & 36.7 & 69 & 63.3 & \multirow[t]{3}{*}{2.73} & \multirow[t]{2}{*}{0.038} \\
\hline$\geq \mathrm{MW}$ & 67 & 73.6 & 24 & 26.4 & & \\
\hline \multicolumn{6}{|l|}{ Number of family member } & \\
\hline$<5$ & 82 & 64.6 & 45 & 35.4 & \multirow[t]{3}{*}{7.88} & \multirow[t]{2}{*}{$<0.001$} \\
\hline$\geq 5$ & 25 & 34.2 & 48 & 65.8 & & \\
\hline \multicolumn{6}{|l|}{ Maternal height } & \\
\hline$<150 \mathrm{~cm}$ & 23 & 32.9 & 47 & 67.1 & \multirow[t]{3}{*}{2.66} & \multirow[t]{3}{*}{0.030} \\
\hline$\geq 150 \mathrm{~cm}$ & 84 & 64.6 & 46 & $35 \cdot 4$ & & \\
\hline \multicolumn{5}{|l|}{ Low birth weight } & & \\
\hline Not LBW & 92 & 63.9 & 52 & 36.1 & \multirow[t]{2}{*}{3.75} & \multirow[t]{2}{*}{0.008} \\
\hline LBW & 15 & 26.8 & 41 & 73.2 & & \\
\hline \multicolumn{7}{|l|}{ Birth length } \\
\hline$<48 \mathrm{~cm}$ & 20 & 26.7 & 55 & $73 \cdot 3$ & \multirow[t]{2}{*}{6.28} & \multirow[t]{2}{*}{$<0.001$} \\
\hline \multirow{2}{*}{\multicolumn{7}{|c|}{ Breastfeeding }} \\
\hline & & & & & & \\
\hline Not exclusive breastfeeding & 28 & 38.4 & 45 & 61.6 & \multirow[t]{3}{*}{2.57} & \multirow[t]{2}{*}{0.041} \\
\hline Exclusive breastfeeding & 79 & 62.2 & 48 & 37.8 & & \\
\hline \multicolumn{6}{|l|}{ Complementary feeding } & \\
\hline Not in time & 27 & 35.1 & 50 & 64.9 & 3.02 & 0.024 \\
\hline In time & 80 & 65.0 & 43 & 35.0 & & \\
\hline
\end{tabular}


Muslimah et al./ Soil Transmitted Helminths and Stunting in Children Aged 6-12 Years Old

\section{The effect of maternal height on stunting}

There was an effect of maternal height on the incidence of stunting in children aged 6-12 years. Children with mothers who have a height $<150 \mathrm{~cm}$ were more likely (logodd) to experience stunting by 1.03 units than children with maternal height of $\geq 150 \mathrm{~cm}$ $(b=1.03 ; 95 \% \mathrm{CI}=0.10$ to $1.96 ; \mathrm{p}=0.030)$.

\section{The effect of LBW on stunting}

There was an effect of LBW on stunting in children aged 6-12 years. Children who have a history of LBW, the likelihood (logodd) of experiencing stunting was 1.45 units higher than children with normal birth weight $(b=1.45 ; 95 \% \mathrm{CI}=0.38$ to 2.51 ; $\mathrm{p}=0.007$ ).

7. The effect of birth length on stunting

There was an effect of body length at birth on the incidence of stunting in children aged 6-12 years. Children who had a history of body length at birth $<48 \mathrm{~cm}$ were more likely (logodd) to experience stunting by
1.91 units higher than children who had a

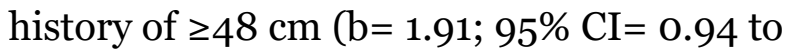
2.87; $\mathrm{p}<0.001$ ).

8. The effect of exclusive breastfeeding on stunting

There was an effect of exclusive breastfeeding on stunting in aged children 6-12 years. Children who had a history of not being exclusively breastfed were more likely (logodd) to experience stunting by 0.96 units than children who had a history of exclusive breastfeeding $(b=0.96 ; 95 \% \mathrm{CI}=$ 0.23 to $1.90 ; p=0.045$ ).

9. The effect of complementary feeding on stunting

There was an effect of complementary feeding on stunting in children aged 6-12 years. Children with inappropriate complementary feeding were more likely (logodd) to experience stunting by 1.11 higher than those with appropriate complementary feeding $(b=1.11 ; 95 \% \mathrm{CI}=0.12$ to $2.11 ; \mathrm{p}=$ o.029).

Table 4. Multiple logistic regression analysis with a multilevel approach Association of Soil Transmitted Helminths and Stunting in Children Aged 6-12 Years Old

\begin{tabular}{|c|c|c|c|c|}
\hline \multirow[b]{2}{*}{ Independent Variables } & \multirow{2}{*}{$\begin{array}{l}\text { Regression } \\
\text { Coefficient } \\
\text { (b) }\end{array}$} & \multicolumn{2}{|c|}{$95 \% \mathrm{CI}$} & \multirow[b]{2}{*}{$\mathbf{p}$} \\
\hline & & $\begin{array}{c}\text { Lower } \\
\text { Limit }\end{array}$ & $\begin{array}{l}\text { Upper } \\
\text { Limit }\end{array}$ & \\
\hline \multicolumn{5}{|l|}{ Fixed effect } \\
\hline Worms infection status (yes) & 2.11 & 1.11 & 3.10 & $<0.001$ \\
\hline Education (low) & 1.08 & 0.13 & 2.03 & 0.025 \\
\hline Income (low) & 1.03 & 0.05 & 2.02 & 0.039 \\
\hline Number of family member $(\geq 5)$ & 2.13 & 1.13 & 3.13 & $<0.001$ \\
\hline Maternal height $(\geq 150 \mathrm{~cm})$ & 1.03 & 0.10 & 1.96 & 0.030 \\
\hline LBW (yes) & 1.45 & 0.38 & 2.51 & 0.007 \\
\hline Birth length $(\geq 48 \mathrm{~cm})$ & 1.91 & 0.94 & 2.87 & $<0.001$ \\
\hline Exclusive breastfeeding (yes) & 0.96 & 0.23 & 1.90 & 0.045 \\
\hline Complementary feeding (yes) & 1.11 & 0.12 & 2.11 & 0.029 \\
\hline Constants & -5.16 & -6.76 & -3.56 & $<0.001$ \\
\hline \multicolumn{5}{|l|}{ Random Effect } \\
\hline Var (Constants) & 0.294 & & & \\
\hline \multicolumn{5}{|l|}{$\mathrm{N}$ observation $=200$} \\
\hline \multicolumn{5}{|l|}{$\mathrm{N}$ group $=25$} \\
\hline \multicolumn{5}{|l|}{ Log Likelihood= -74.19 } \\
\hline \multicolumn{5}{|l|}{$\operatorname{Min}=8, \max =8$} \\
\hline $\mathrm{p}=<0.001$ & & & & \\
\hline $\mathrm{ICC}=8.2 \%$ & & & & \\
\hline
\end{tabular}




\section{The effect of village on stunting}

Village had a contextual effect on stunting (ICC $=8.2 \%$ ). The variation in the incidence of stunting was $8.2 \%$ influenced by the subdistrict. The ICC value in this study was in accordance with the rule of thumb (8-10\%), so the contextual influence in this study was important.

\section{DISCUSSION}

1. The relationship between worms and stunting

The results in this study indicated that worms had a relationship with the incidence of stunting. In this study, it is known that children aged 6-12 years who have worms can cause stunting.

According to Susilowati and Quyumi, in 2017, infectious diseases that can cause malnutrition or stunting are worm infections. Worms can cause a decrease in children's appetite which results in loss of carbohydrates, protein and loss of blood and other nutrients needed by the body, thereby reducing the quality of human resources (Onis and Branca, 2016). In the long term, this can affect children's learning achievement, because the child's motor, cognitive and verbal development is impaired. Children with disabilities who are stunted may experience interference with the maturation process of brain neurons and changes in brain structure and function (Yadika et al. 2019).

\section{The relationship between maternal education and stunting}

The results in this study indicate that maternal education has a relationship with the incidence of stunting. In this study, it is known that children aged 6-12 years with mothers with low education cause the incidence of stunting.

This is in line with research conducted by Utami et al. (2017) which showed that there is an indirect effect of maternal edu- cation on the incidence of stunting, maternal education affects protein intake and energy intake which indirectly affects stunting status. The majority of mothers have tertiary education, namely high school and tertiary education, but mothers with higher education levels are not always knowledgeable, because knowledge is not only obtained from formal education but also from non-formal education (Senbanjo et al. 2011).

\section{The relationship between family income and stunting}

The results in this study indicated that family income has a relationship with the incidence of stunting. In this study, it is known that children aged 6-12 years with low-income families can cause stunting.

Families with sufficient or high income are able to buy food that is better in quality and quantity so that the family's nutritional needs can be fulfilled, this is a reflection of good nutritional behavior. According to Handini (2013), income and nutritional status have a significant relationship.

\section{The relationship between number of family member and stunting}

The results in this study indicated that the number of family members has a relationship with the incidence of stunting. In this study, it is known that children aged 6-12 years with a number of family members $\geq 5$ can cause stunting.

There is an effect of the number of family members ( $\geq 4$ family members) on the incidence of stunting (Sugiyanto et al. 2019). Having a large number of family members ( $\geq 5$ family members) and low economic status can make family members have limitations and competition in terms of providing and getting food that is nutritionally balanced.

The large number of children in families with sufficient and stable economic 
status can cause reduced love and attention from mothers to child development, but it is not absolutely a risk factor for the incidence of stunting, it is necessary to pay attention to various other risk factors (Suciningtyas et al. 2019).

\section{The relationship between maternal height and stunting}

The results in this study indicated that maternal height has a relationship with the incidence of stunting. In this study, it is known that children aged 6-12 years with mothers who are $<150 \mathrm{~cm}$ can cause stunting.

Maternal height is a predictor factor in reducing the prevalence of stunting. Children with mothers who have a height of $\geq 154 \mathrm{~cm}$ have a prevalence of $78 \%$ lower than children whose mothers have a height of $<154 \mathrm{~cm}$ (Dekker et al. 2010).

6. The relationship between $\mathrm{LBW}$ and stunting

The results in this study indicated that LBW has a relationship with the incidence of stunting. In this study, it is known that children aged 6-12 years with a history of LBW can cause stunting.

Ntenda (2019) stated that compared to children with normal birth weight, children who experience LBW have a higher chance of experiencing stunting in Malawi. Likewise what happened in Bangladesh, research done by Rahman et al. (2016) stated that there is a positive relationship between LBW and malnutrition in children, the percentage of malnourished children born with LBW is greater than children born with normal weight, although other variables have been controlled.

\section{The relationship between birth length and stunting}

The results in this study indicated that birth body length has a relationship with the incidence of stunting. In this study it was found that children aged 6-12 years with a history of birth length $<48 \mathrm{~cm}$ caused the incidence of stunting.

The results of a study conducted in Pinrang Regency are in line with the results of research conducted by Ilma, Salimo and Pamungkasari (2019) in Kupang, which stated that children with a long history of normal birth weight reduce the risk of stunting. Child birth length significantly increases the risk of stunting by up to 2 years in an early life, which can increase the risk of various chronic diseases.

\section{The relationship between exclusive breastfeeding and stunting}

The results in this study indicated that exclusive breastfeeding has a relationship with the incidence of stunting. In this study it is known that children aged 6-12 years who do not have a history of exclusive breastfeeding can cause stunting.

Akombi et al. (2017) found that there was a relationship between the length of breastfeeding and the incidence of stunting. Children who were exclusively breastfed for more than 12 months were more likely to be stunted than children who were exclusively breastfed for 6 months.

Breastmilk given to children early in life can provide immediate and long-term protection against infection. The content of breast milk in the form of various immunity, anti-microbial, anti-inflammatory and nutritional properties can protect children from diseases that can be carried by fluids or other foods contaminated by infectious agents (Nigatu et al. 2019).

\section{The relationship between comple- mentary feeding and stunting}

The results in this study indicate that complementary foods have a relationship with the incidence of stunting. In this study, it is known that children aged 6-12 years who do not have a history of complementary foods can cause stunting. 
Hijra et al. (2016) stated that there is a relationship between complementary feeding and the incidence of stunting, children who do not get complementary foods have an increased risk of stunting by 8.26 times than children who get complementary foods on time.

Impaired growth in children is caused by malnutrition experienced since they were in the womb, inappropriate timing of complementary feeding, inadequate complementary solids and inappropriate complementary patterns according to the child's age. The provision of solid foods must fulfill the requirements for quantity, time, texture, variety of food, method of administration and adequate hygiene principles (Rakhmahayu et al. 2019).

\section{The contextual effect of village on stunting}

The results in this study indicated that the context of the sub-district has a relationship with the incidence of stunting. The value of the contextual influence of the subdistrict with the regional topographic strata at the second level is shown by the ICC value of $8.2 \%$.

A study Leo et al. (2018) stated that the risk factors for stunting in the highlands and lowlands areas have differences and this indirectly affects the incidence of stunting, while differences in risk factors in each region include the level of energy sufficiency and the level of protein adequacy and a history of exclusive breastfeeding. Children who live in the lowlands have a tendency to consume more carbohydrates, foods that contain carbohydrates are mostly obtained from large portions of rice and regular meals at all times. In addition, most children who live in the lowlands also eat snacks such as sponge cakes and various other snacks (Rahma et al., 2018).

This is in line with Indrastuty and Pujiyanto (2019), which showed that the place of residence as a child's domicile has a significant relationship with the opportunity for the incidence of stunting. Access to health facilities is one of the causes of the incidence of stunting under five, while the affordability of access to health services in the regions is one of the targets for stunting management interventions.

\section{AUTHOR CONTRIBUTION}

Putri Andini Muslimah as the main author has the role in collecting data, formulating data, designing study, conducting questionnaire reliability test and analyzing data. Harsono Salimo advised discussion of study and writing techniques. Yulia Lanti Retno Dewi examined the data, provided input on study discussions and writing techniques.

\section{CONFLICT OF INTEREST}

There was no conflict of interest in this study.

FUNDING AND SPONSORSHIP

This study used personal funds of the main researcher.

\section{ACKNOWLEDGEMENT}

The researchers expresses their gratitude to all Heads of villages in Pinrang Regency who have allowed this study to be carried out. Thank you to all the children aged 6-12 years who have been willing and cooperative to be the study subjects.

\section{REFERENCE}

Akombi BJ, Agho KE, Hall JJ, Merom D, Astell-Burt T, Renzaho MN (2017). Stunting and severe stunting among children under-5 years in Nigeria: A multilevel analysis. BMC Pediatr, 17(1): 1-16. doi: 10.1186/s12887-016o770-z.

Andriani M (2014). Peranan gizi dalam siklus kehidupan. (The role of nutri- 
Muslimah et al./ Soil Transmitted Helminths and Stunting in Children Aged 6-12 Years Old

tion in the cycle of life.) Jakarta: Kencana Prenadamedia Group.

Azriful, Bujawati E, Habibi, Aeni S, Yusdarif (2018). Determinan kejadian stunting pada balita usia 24-59 bulan di Kelurahan Rangas Kecamatan Banggae Kabupaten Majene (Determinants of stunting incidence in children age 24-59 months in Rangas Village, Banggae District, Majene Regency). Al-sihah: The Public Health Science Journal. 10(2): 192-203. doi: 10.24252/as.v10i2.6874.

Candra A (2011). Hubungan underlying factor dengan kejadian stunting pada anak 1-2 tahun (The relationship between underlying factor and stunting in children aged 1-2 years). J Nutr Health. doi: 10.4324/978131508241724.

Dekker LH, Mora-Plazas M, Marin C, Baylin A, Villamor E (2010). Stunting associated with poor socioeconomic and maternal nutrition status and respiratory morbidity in Colombian schoolchildren. Food Nutr Bull, 31(2): 242-250. doi: 10.1177/156482651003100207.

Dinas Kesehatan Provinsi Sulawesi Selatan (2018). Data stunting Provinsi Sulawesi Selatan (South Sulawesi Province stunting data). Dinas Kesehatan Provinsi Sulawesi Selatan. Makassar.

Fitria N (2017). Hubungan faktor asupan makanan dan kondisi penyakit dengan kejadian stunting pada anak balita di wilayah kerja puskesmas Barombong Kota Makassar (The relationship between food intake factors and disease conditions with the incidence of stunting in children under five in the working area of the Barombong Community Health Center, Makassar City). Skripsi. Makassar: Universitas Islam Negeri Alauddin
Makassar.

Hagos S, Hailemariam D, Woldehanna T, Lindtjørn B (2017). Spatial heterogeneity and risk factors for stunting among children under age five in Ethiopia: A Bayesian geo-statistical model. PLoS ONE, 12(2):1-18. doi: 10.1371/journal.pone.0170785.

Handini D, Ichsan B, Nirlawati DD (2013). Hubungan tingkat pendapatan keluarga dengan status gizi balita di Wilayah Kerja Puskesmas Kalijambe (The relationship between family income level and nutritional status of children under five in the working area of Kalijambe Health Center). Biomedika, 5(2). doi: 10.23917/biomedika.v5i2.263.

Hijra H, Muis FS, Kartasurya MI (2016). Inappropriate complementary feeding practice increases risk of stunting in children aged 12-24 months. Univmed, 35(3): 146. doi: 10.18051/univmed.2016.v35.146-155.

Ibrahim IA, Bujawati E, Syahrir S, Adha AS, Mujahida (2019). Analisis determinan kejadian growth failure (stunting) pada anak balita usia 12-36 bulan di Wilayah Pegunungan Desa Bontongan Kecamatan Baraka Kabupaten Enrekang (Determinant analysis of the incidence of growth failure (stunting) in children aged 12-36 months in the mountainous area of Bontongan Village, Baraka District, Enrekang Regency). Al-sihah: The Public Health Science Journal, 11(1): 50-64. doi: 10.24252/as.v11i1.9418.

Ilma NN, Salimo H, Pamungkasari EP (2019). Prevalence and path analysis on the effects of diarrhea and life course determinants on stunting in children under two years of age in Kupang, East Nusa Tenggara. Matern Child Health J, 4(4): 230-241. doi: 
Muslimah et al./ Soil Transmitted Helminths and Stunting in Children Aged 6-12 Years Old

10.26911/thejmch.2019.04.04.02.

Indrastuty D, Pujiyanto P (2019). Determinan sosial ekonomi rumah tangga dari balita stunting di Indonesia: Analisis Data Indonesia Family Life Survey (IFLS) 2014 (Household socio-economic determinants of childhood stunting in Indonesia: Data Analysis of the 2014 Indonesia Family Life Survey (IFLS)). Jurnal Ekonomi Kesehatan Indonesia, 3(2). doi: 10.7454/eki.v3i2.3004.

Kementerian Kesehatan Republik Indonesia (2013). Buku saku pelayanan kesehatan neonatal esensi (Neonatal health service essential pocket book). Kementerian Kesehatan Republik Indonesia. Jakarta.

Kementerian Kesehatan Republik Indonesia (2018a). Buletin Stunting (Stunting Bulletin). Kementerian Kesehatan Republik Indonesia. Jakarta.

Kementerian Kesehatan Republik Indonesia (2018b). RISKESDAS 2018: Executive Summary. Kementerian Kesehatan Republik Indonesia. Jakarta.

Kusumawardhani I (2017). ASI eksklusif, panjang badan lahir, berat badan lahir rendah sebagai faktor risiko terjadinya stunting pada anak usia 624 bulan di Puskesmas Lendah II Kulon Progo (Exclusive breastfeeding, birth length, low birth weight as risk factors for stunting in children aged 6-24 months at Puskesmas Lendah II Kulon Progo). Skripsi. Yogyakarta: Politeknik Kesehatan Kementerian Kesehatan Yogyakarta.

Leo AR, Subagyo HW, Kartasurya MI (2018). Faktor risiko stunting pada anak usia 2-5 tahun di wilayah gunung dan pesisir pantai (Risk factors for stunting in children aged 2-5 years in mountain and coastal areas). Jurnal Gizi dan Pangan Soe- dirman, 2(1): 51. doi: 10.20884/1.jgpS.2018.2.1.512.

Susilowati E, Quyumi ER (2019). Peningkatan status gizi dan penurunan infeksi cacing pada anak toddler dengan penerapan dinamika kelompok sosial (Increasing nutritional status and decreasing worm infection in toddlers by application of social group dynamics). J Chem Inf Model, 53(9): 1689-1699. doi: 10.1017/CBO9781107415324.004.

Nigatu D, Azage M, Motbainor A (2019). Effect of exclusive breastfeeding cessation time on childhood morbidity and adverse nutritional outcomes in Ethiopia: Analysis of the demographic and health surveys. PLoS ONE, 14 (10):1-12. doi: 10.1371/journal.pone.0223379.

Ntenda PAM (2019). Association of low birth weight with undernutrition in preschool-aged children in Malawi. Nutrition Journal, 18(1): 1-15. doi: 10.1186/s12937-019-0477-8.

Onis MD, Branca F (2016). Childhood stunting: A global perspective. Matern Child Nutr, (12): 12-26. doi: 10.1111/mcn.12231.

Paramashanti BA, Hadi H, Gunawan IMA (2016). Pemberian ASI eksklusif tidak berhubungan dengan stunting pada anak usia 6-23 bulan di Indonesia (Exclusive breastfeeding is not associated with stunting in children aged 6-23 months in Indonesia). IJND, 3(3): 162. doi: 10.21927/ijnd.2015.3(3).162-174.

Rahma N, Hasanah, Nurfadilah (2018). Perbedaan tingkat kecukupan energi, protein dan status gizi anak sekolah dasar negeri daerah pantai dan daerah pengunungan Kecamatan Sindue (The difference in the level of energy, protein and nutritional status of 
public elementary school children in coastal areas and mountainous areas of Sindue District). Jurnal Kesehatan, 3(6): 48-6o.

Rahman MS, Howlade T, Masud MS, Rahman ML (2016). Association of low-birth weight with malnutrition in children under five years in Bangladesh: Do mother's education, socioeconomic status, and birth interval matter. PLoS ONE. 11(6): 1-16. doi: 10.1371/journal.pone.0157814.

Rakhmahayu A, Dewi YLR, Murti B (2019). Logistic regression analysis on the determinants of stunting among children aged 6-24 months in Purworejo Regency, Central Java. Matern. Child Health J, 4(3): 158-169. doi: 10.26911/thejmch.2019.04.03.03.

Suciningtyas PD, Triharini M, Rachmawati PD (2019). Hubungan data demografi keluarga dalam pemberian ASI esklusif anak balita stunting (Relationship of family demographic data in exclusive breastfeeding for stunting in children). Pediomaternal Nursing Journal, 5(1): 132. doi: 10.20473/pmnj.v5i1.13133.

Sugiyanto J, Raharjo SS, Dewi YLR (2019). The effects of exclusive breastfeeding and contextual factor of village on stunting in Bontang, East Kalimantan, Indonesia. J Epidemiol Public Health. 4(3): 222-233. doi: 10.26911/jepublichealth.2019.04.03.10.
Swathma D, Lestari H, Ardiansyah RT (2016). Analisis faktor risiko BBLR, panjang badan bayi saat lahir dan riwayat imunisasi dasar terhadap kejadian stunting pada balita usia 1236 bulan di Wilayah Kerja Puskesmas Kandai Kota Kendari Tahun 2016 (Analysis of LBW risk factors, baby body length at birth and history of basic immunization against the incidence of stunting in toddlers aged 1236 months in the Work Area of the Kandai Health Center, Kendari City, 2016). E-Journal Unsyiah, 1(3): 1-10.

UNICEF/WHO/World Bank Group (2019). Levels and trends in child malnutrition: key findings of the 2019 Edition of the Joint Child Malnutrition Estimate. 1-15. Available at: https://www.who.int/nutgrowthdb/jme-2019-key-findings.pdf?ua $=1 \%$.

Utami AD, Indarto D, Dewi YLR (2017). The effect of nutrient intake and socioeconomic factor toward stunting incidence among primary school students in Surakarta. J Epidemiol Public Health, 2(1): 1-10. https://doi.org/jepublichealth.2017.02.01.01.

Yadika ADN, Berawi KN, Nasution SH (2019). Pengaruh stunting terhadap perkembangan kognitif dan prestasi belajar (The effect of stunting on cognitive development and learning achievement). Jurnal Majority, 8(2): 273-282. 